\title{
Development of Reverse Transcriptase Polymerase Chain Reaction Primer Sets and Standard Positive Control Capable of Verifying False Positive for the Detection of Severe acute respiratory syndrome coronavirus 2
}

\author{
Kyu Bong Cho ${ }^{\dagger ; *}$ \\ Department of Biomedical Laboratory Science, Shinhan University, Uijeongbu 11644, Korea
}

\begin{abstract}
Severe acute respiratory syndrome coronavirus (SARS-CoV2) is a major coronavirus that infects humans with human Coronavirus (HuCoV)-229E, HCoV-OC43, HCoV-HKU1, HCoV-NL63, Severe acute respiratory syndrome coronavirus (SARS-CoV) and Middle east respiratory syndrome coronavirus (MERS-CoV). SARS-CoV2 is currently a global pandemic pathogen. In this study, we developed conventional RT-PCR based diagnostic system for the detection of SARS-CoV2 which is relatively inexpensive but has high stability and a wide range of users. Three conventional RTPCR primer sets capable of forming specific band sizes by targeting the ORF1ab [232 nucleotide (nt)], E (200 nt) and N (288 nt) genes of SARS-CoV2 were developed, respectively, and it were confirmed to be about 10 100 times higher detection sensitivity than the previously reported methods. In addition, a standard positive control that can generate specific amplicons by reacting with the developed RT-PCR primers and verify the false-positiv from contamination of the laboratory was produced. Therefore, the diagnostic system that uses the RT-PCR method is expected to be used to detect SARS-CoV2.
\end{abstract}

Key Words: Conventional RT-PCR, SARS-CoV2, Severe acute respiratory syndrome coronavirus, Standard positive control

\section{서 론}

중증급성호흡기증후군 코로나바이러스2(Severe acute respiratory syndrome coronavirus 2; SARS-CoV2)는 2019년 사람에게 발생이 보고된 후, 세계보건기구에서 2020년 1 월 국제적 공중보건 비상사태를 선언하였으며 3월에는 세계적 대유행을 의미하는 팬데믹이 선언되어 현재까지 도 전 세계적으로 문제가 되고 있다(Gorbalenya et al., 2020; van Doremalen et al., 2020). SARS-CoV2는 에어로졸, 호흡 기 비말 등을 통해 감염될 수 있고, 기관지와 폐에서 증 식하며, 고열, 마른기침, 호흡곤란, 폐렴, 심부전 등의 증
상 또는 질환을 유발한다(Andersen et al., 2020; Zhou et al., 2020). SARS-CoV2 진단은 항원-항체 반응을 이용한 방 법과 특정 핵산 단편을 증폭하는 중합효소연쇄반응(polymerase chain reaction; PCR) 기반의 방법이 혼용되고 있 으나(Carroll and McNamara, 2021; Corman et al., 2020; Domenico et al., 2021), 우수한 검출 민감도를 바탕으로 하 는 PCR 기반의 방법이 주요 기술로 활용되고 있으며 이 중에서도 실시간(real-time) 역전사 정량 PCR [reverse transcription quantitative PCR; RT-qPCR]이 주로 활용되고 있 다(Corman et al., 2020; Carroll and McNamara, 2021). 그러나 RT-qPCR에 포함되는 프로브와 시약은 일반 RT-PCR에 비 해 상대적으로 고가로 개발도상국 등에서의 지속적 활용

Received: October 21, 2021 / Revised: November 22, 2021 / Accepted: November 22, 2021

*Professor.

${ }^{\dagger}$ Corresponding author: Kyu Bong Cho. Department of Biomedical Laboratory Science, Shinhan University, 95, Hoam-ro, Uijeongbu-si, Gyeonggi-do 11644 , Korea

Tel: +82-31-870-3712, Fax: +82-31-870-3719, e-mail: kbcho@shinhan.ac.kr

(C) The Korean Society for Biomedical Laboratory Sciences. All rights reserved.

(C) This is an Open Access article distributed under the terms of the Creative Commons Attribution Non-Commercial License (http:/creativecommons.org/licenses/by-nc/3.0/) which permits unrestricted non-commercial use, distribution, and reproduction in any medium, provided the original work is properly cited. 
에 한계가 있고, 또한 염기서열을 바탕으로 한 유전형 분 석에 제한이 있어 모니터링 이 후의 연구에도 한계가 있 다(Lee and Cho, 2019). 반면 일반 RT-PCR은 오랜 연구로 안정성 검증 및 사용자의 범위가 넓고, 저가로 개발도상 국 등에서도 활용될 수 있으며, 염기서열 분석이 가능하 여 유전형 분석 등 후속 연구의 가능성이 높은 등의 진단 기술로의 장점을 가지고 있다(Yamashita et al., 2003; Reuter et al., 2009; Santos et al., 2015; Lee and Cho, 2019). SARS$\mathrm{CoV} 2$ 는 단일 선형 $\mathrm{RNA}$ 분절의 핵산 중 주로 Orflab $(\mathrm{RdRp}), \mathrm{N}$ 및 $\mathrm{E}$ gene을 대상으로 PCR 진단 기술이 구축되 고 있다(Corman et al., 2020). 그러나 SARS-CoV2 진단을 위해 보고된 몇몇 방법들은 대체적으로 한 유전자를 대 상으로 하고 있으며 각 방법 간의 비교 연구가 미흡하다. 한편, PCR 기반의 진단기법은 결과의 확실성을 위해 실 험 결과에 항상 활성 및 비활성을 가지는 양성 및 음성 대조물질이 요구되며, 이 중 양성대조물질은 병원체 검사 의 정확성, 정밀성 및 재현성에 대한 보장을 위해 반드시 필요하다(Jung et al., 2018). 그러나 병원체에 감염된 시료 또는 핵산을 활용하기에는 검사자의 감염 위험성 등의 문제가 있고, 보고된 염기서열 일부를 합성하여 plasmid 형태로 사용하는 것은 양성대조군으로부터 오염으로 인 한 위양성 반응을 검증할 수 없다는 한계점이 보고된 바 있다(Lee, 2013; Cho, 2018). 따라서 본 연구에서는 일반 RT-PCR 기반으로 3종류의 유전자에 대해 SARS-CoV2를 진단할 수 있는 프라이머 조합을 개발하여 기존 보고된 방법들과 비교하였으며, 개발한 프라이머 조합들의 특이 결합 및 위양성 반응을 검정할 수 있는 표준양성대조군 을 개발하였다.

\section{재료 및 방법}

\section{핵산 수집 및 프라이머 설계}

SARS-CoV2[미국국립생물정보센터(National center for biotechnology information (NCBI) accession number NC_045512.2 기준 Orflab (15,347 15,614), E (26,246 26,471) 및 $\mathrm{N}(28,622 \sim 28,917)]$, SARS [NC 004718.3 기준 Orflab (15,277 15,544), E (26,117 26,347), N (28,471 28,766)] 및 Middle east respiratory syndrome coronavirus (MERS-CoV) NC_019843.3 기준 Orflab (15,301 15,600), E (27,590 $27,838), \mathrm{N}(28,585$ 28,836)]를 대상으로 하였고, vector에 접합되는 부위로 제한효소 NruI (TCGCGA) 및 PstI (CTG$\mathrm{CAG}$ )으로 하여 (주)Marcrogen (Seoul, Korea)에서 핵산을
합성하였다. 또한 human coronavirus (HCoV)-229E와 호흡 기 아데노바이러스(respiratory Adenovirus; R-AdV)는 vircell (Granada, Spain)을 통해 RNA를 수집한 후 ReverTra Ace$\alpha^{-}{ }^{\mathrm{TM}}$ (Toyobo, Osaka, Japan)을 사용하여 cDNA로 합성하였 다. 한편, 프라이머의 설계를 위하여 $\mathrm{NCBI}$ 에서 SARS$\mathrm{CoV} 2$ (NC_045512.2) 및 사람에게 감염되는 그 밖의 코 로나바이러스 6종[SARS-CoV (NC_004718.3), MERS-CoV (NC_019843.3), HCoV-OC43 (NC_006213.1), HCoV-229E (NC_002645.1), HCoV-NL63 (NC_0065831.2) 및 HCoVHKU1 (NC_006577.2)] 염기서열을 수집하였다. Primer 3 ver.0.4.0.을 이용하여 픽킹한 프라이머를 BioEdit version 7.2.6 (Hall, 1999) software package에서 수집한 염기서열들과 함께 다중 염기서열 정렬하여 특이성을 검증하였고, Oligo Calculator version 3.27에서 잠재적 헤어핀 구조 형성 등 이 론적 문제점을 검토 후 각 유전자 별 후보 프라이머를 선정하였다.

\section{프라이머 선발 및 비교}

$\mathrm{PCR}$ 증폭이 가능한 프라이머 조합의 구성, SARS-CoV2 에 특이적 반응, 참고 바이러스 4종 핵산(SARS-CoV, MERS-CoV, HuCoV-229E 및 R-AdV)에 비특이적 반응 및 검출 민감도 시험을 이용한 프라이머 조합 선발 과정, PCR 조성 및 조건은 기존 보고했던 Lee and Cho (2019) 와 동일하게 수행하였다. 특이적 반응에 활용한 각 핵산 의 농도는 모두 $1 \mathrm{pg} / \mu \mathrm{L}$ 이었으며, 비 특이적 반응에 사용 된 핵산의 농도는 SARS-CoV와 MERS-CoV는 $1 \mathrm{pg} / \mu \mathrm{L}, \mathrm{R}-$ $\mathrm{AdV}$ 는 100 copies로 하였다. 또한 인위적 감염을 통한 검 출 민감도를 검정하기 위하여 건강한 사람의 호흡기 시 료를 채취하였고, GeneAll ${ }^{\circledR}$ Ribospin $^{\mathrm{TM}} \mathrm{vRD}$ (GeneAll, Korea) 로 총 RNA를 추출 후 ReverTra Ace- $\alpha^{-}{ }^{\mathrm{TM}}$ (Toyobo)로 cDNA 합성하였으며, 합성한 시료 total cDNA를 용매로 하여 튜 브 내에서 SARS-CoV2 핵산을 농도 별로 인위적 감염시 켰다. 한편, 기존 보고된 SARS-CoV2 RT-PCR 방법 중 본 연구에서 합성한 핵산에 결합할 수 있는 4 개 프라이머 (Corman et al., 2020; Mollaei et al., 2020)를 대상으로 하여 비특이적 반응 및 검출 민감도 등을 비교하였다.

\section{표준양성대조군 설계, 제작 및 평가}

제작 및 합성한 양성 핵산을 바탕으로 EZchange ${ }^{\mathrm{TM}}$ sitedirected mutagenesis kit (Enzynomics, Korea)를 이용하여 프 로토콜에 따라 염기서열을 삽입하였으며, ORF1ab, E 및 $\mathrm{N}$ gene의 프라이머 서열이 결합하는 산물 안쪽으로 제한 


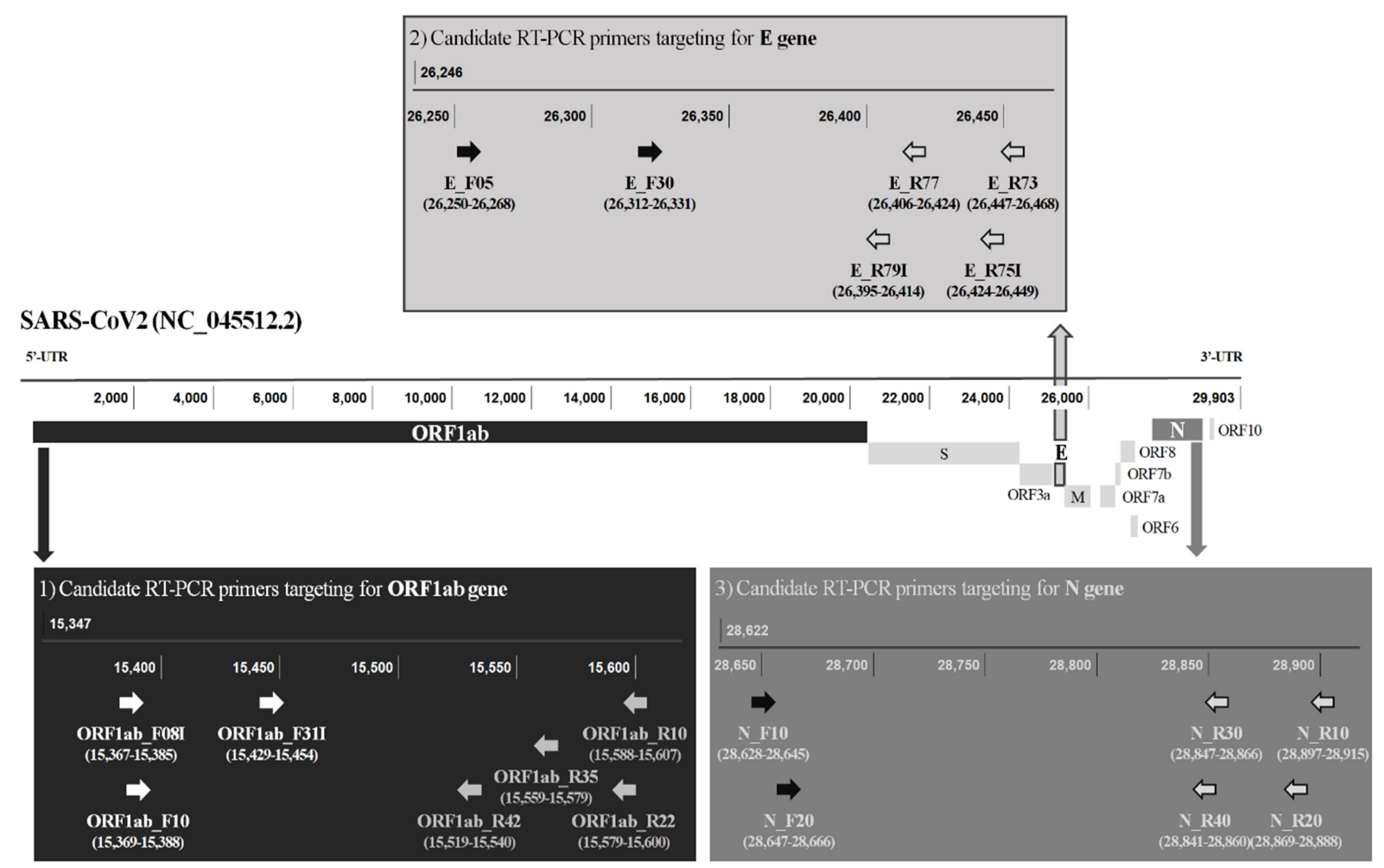

Fig. 1. Map of specific candidate RT-PCR primers capable of diagnosing SARS-CoV2 ORF1ab, E and N genes, respectively.

효소 EcoR V (GATATC)가 포함될 수 있도록 하였다(Lee et al., 2015). 제작한 핵산을 $1 \mathrm{pg} / \mu \mathrm{L}$ 로 하여 선발한 3 종류의 프라이머 조합으로 RT-PCR 하였으며, 증폭산물을 MEGA quick-spin Plus Fragment DNA Purification Kit (iNtRON, Daejeon, Korea)로 정제 후 sequencing을 통해 염기서열 삽 입 여부를 확인하였다. 한편, 증폭 산물은 EcoR V (Enzynomics) $37^{\circ} \mathrm{C}$ 에서 $1 \mathrm{hr}$ 반응하였다. 최종 산물 $5 \mu \mathrm{L}$ 를 $6 \mathrm{X}$ loading dye (Enzynomics) $1 \mu \mathrm{L}$ 와 섞어 $2 \%$ agarose gel에서 전기영동 후 $\mathrm{UV}$ 하에서 결과를 관찰하였다. 제작된 염기 서열은 향후 표준양성대조군의 안정적 보존 및 활용을 위하여 클로닝하였다.

\section{결과 및 고찰}

\section{프라이머 설계 및 PCR 조합 구성}

SARS-CoV2 진단을 위하여 3 개 유전자로부터 각각 검 토한 결과, ORF1ab 유전자 7개(정방향 3개 및 역방향 4 개), $\mathrm{E}$ 유전자 6 개(정방향 2개 및 역방향 4개), $\mathrm{N}$ 유전 자 6개(정방향 2개 및 역방향 4개)가 후보 프라이머로 선 택되었다(Fig. 1). 또한 각각의 유전자 별 PCR 조합 수는
ORF1ab 유전자 11 개, $\mathrm{E}$ 유전자 7개 및 $\mathrm{N}$ 유전자 12 개였다.

\section{프라이머 선발 및 비교}

SARS-CoV2의 ORF1ab 유전자 부분을 검출할 수 있는 RT-PCR 프라이머 11 개 조합 중 반응의 세기와 산물의 크 기에 따라 조합 ORF1ab_\#06을 선발하였다. RT-PCR 프 라이머 조합 ORF1ab_\#06은 참고바이러스 핵산들과 반 응하지 않아 SARS-CoV2 특이적 증폭이 추정되었으며, plasmid 기반 검출 민감도 $10^{-7}(=100 \mathrm{ag} / \mu \mathrm{L}$ 수준 $)$ 및 인위 적 감염에 따른 검출 민감도 $10^{-5}$ 수준 $(=10 \mathrm{fg} / \mu \mathrm{L})$ 으로 나 타남에 따라 SARS-CoV 검출에 적합한 프라이머 조합 으로 확인되었다(Fig. 2A). E 유전자 부분을 검출할 수 있는 RT-PCR 프라이머 7개 조합 중 반응의 세기가 가장 우수하게 나타난 조합 E\#02를 선발하였다. RT-PCR 프라 이머 조합 E\#02는 참고바이러스 핵산에 비 특이적 반응 이 나타나지 않았으며, plasmid 기반 검출 민감도 및 인위 적 감염에 따른 검출 민감도 모두 $10^{-6}$ 수준 $(=1 \mathrm{fg} / \mu \mathrm{L})$ 으 로 나타남에 따라 SARS-CoV2 검출용으로 우수한 프라 이머 조합으로 나타났다(Fig. 2B). N 유전자 부분을 검출 할 수 있는 RT-PCR 프라이머 12개 조합 중 반응의 세기 
A

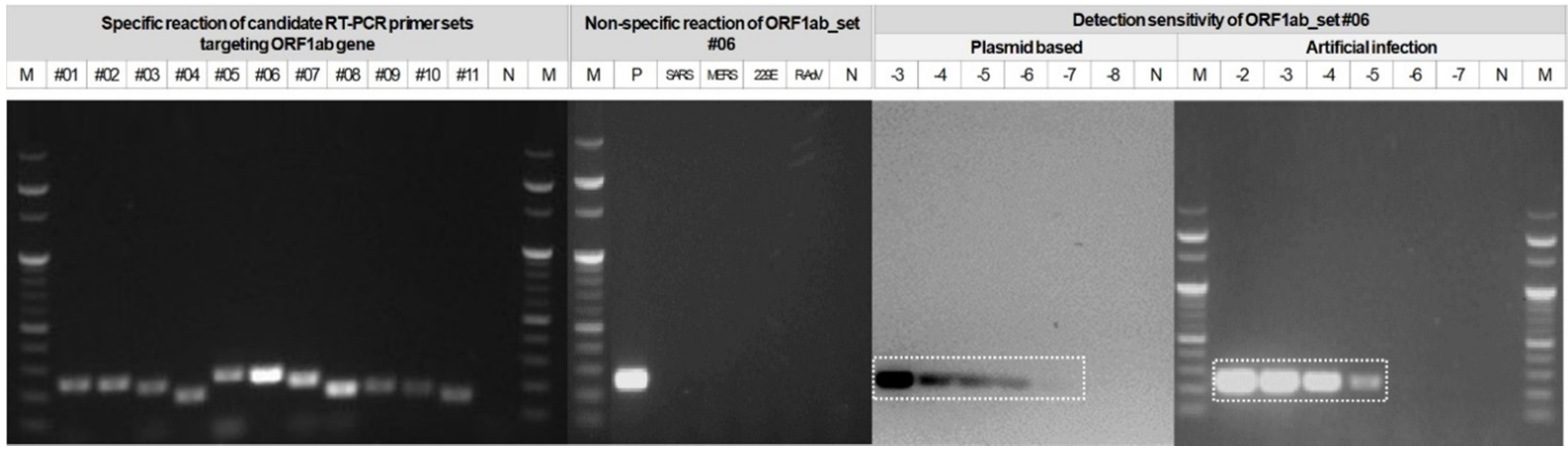

B

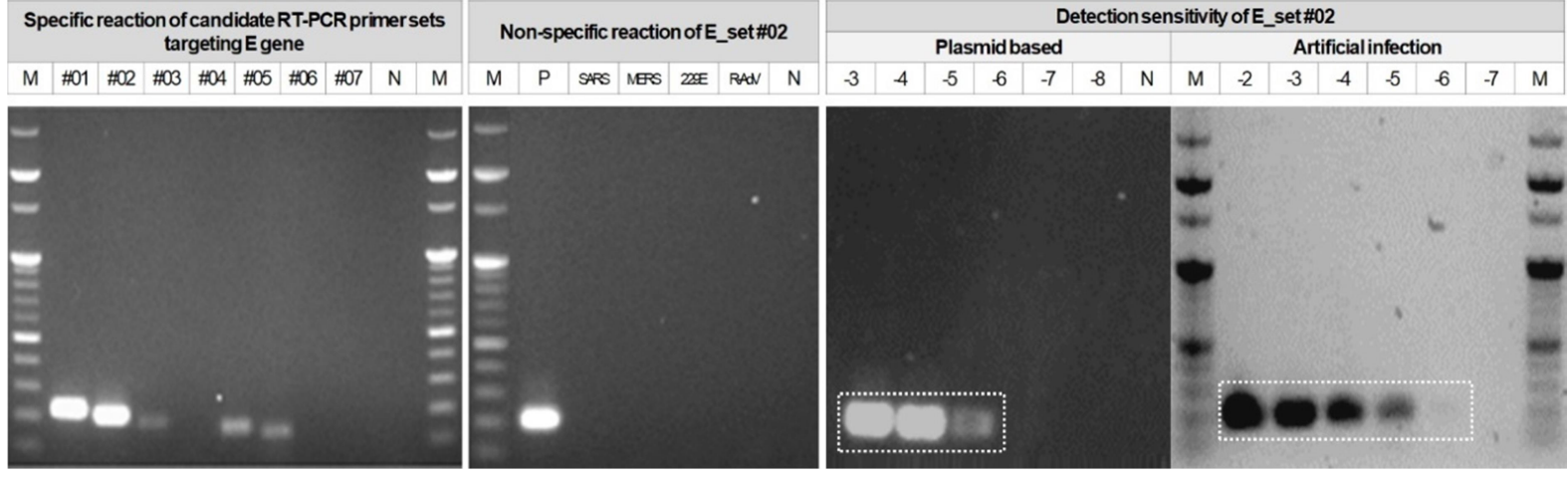

C
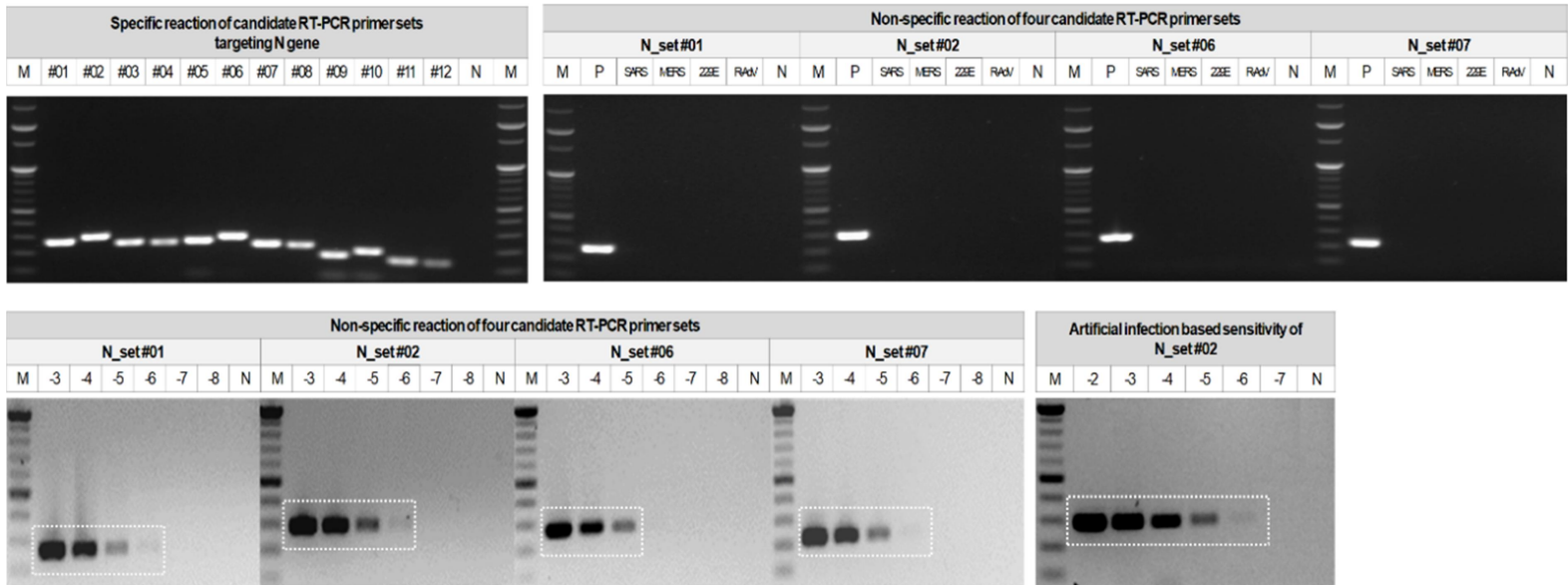

Fig. 2. Specific reaction and sensitivity test of candidate RT-PCR primer sets associated with three genes, respectively. Panel A, Specific reaction and sensitivity test of RT-PCR primer sets targeting ORF1ab gene. Panel B, E gene. Panel C, N gene. Lane M, 100 bp Ladder maker (Enzynomics, Korea); \#01 \#12, number of candidate RT-PCR primer sets each genes; N, negative control; P, positive

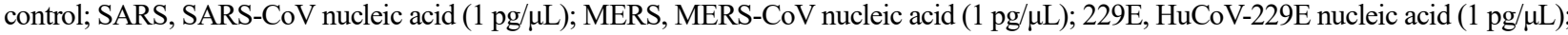
R-AdV, respiratory Adenovirus (100 copies).

와 산물의 크기 중 가장 적합한 4개 조합(N_\#01, N_\#02, $\mathrm{N} \# 06$ 및 $\mathrm{N} \# 07)$ 이 선발되었다. 모든 조합들은 참고바이 러스 핵산에 비 특이적 반응이 나타나지 않아 SARS-CoV
만을 특이적으로 검출할 수 있는 프라이머 조합으로 추 정됨에 따라 plasmid 기반 검출 민감도를 비교하여 상대 적으로 가장 우수한 N_\#02를 선발하였으며, 인위적 감염 
Table 1. Information of final selectived and reference RT-PCR primer sets for the detection of SARS-CoV2

\begin{tabular}{|c|c|c|c|c|c|c|c|c|}
\hline \multirow[b]{2}{*}{ Division } & \multirow[b]{2}{*}{$\begin{array}{l}\text { Target } \\
\text { gene }\end{array}$} & \multirow[b]{2}{*}{ Set\# } & \multicolumn{3}{|c|}{ Primer information and PCR product size } & \multirow[b]{2}{*}{ References } & \multicolumn{2}{|c|}{ Results } \\
\hline & & & Name & Sequence $\left(5^{\prime} \rightarrow 3^{\prime}\right)$ & $\begin{array}{l}\text { PCR } \\
\text { product } \\
\text { Length } \\
\text { (nt) }\end{array}$ & & $\begin{array}{l}\text { Presence of } \\
\text { nonspecific } \\
\text { reaction }\end{array}$ & $\begin{array}{c}\text { Sensitivity } \\
\text { based on } \\
\text { SARS-CoV2 } \\
\text { plasmid }\end{array}$ \\
\hline \multirow{6}{*}{ Development } & \multirow{2}{*}{ ORF1ab } & \multirow[t]{2}{*}{ ORF1ab_\#06 } & O_F10 & AACGTGTTGTAGCTTGTCAC & \multirow{2}{*}{232} & \multirow{6}{*}{ This study } & \multirow[t]{2}{*}{$\times$} & \multirow{2}{*}{$\begin{array}{c}10^{-7} \\
(100 \mathrm{ag} / \mu \mathrm{L})\end{array}$} \\
\hline & & & O_R22 & GACATACTTATCGGCAATTTTG & & & & \\
\hline & \multirow[t]{2}{*}{ E } & \multirow[t]{2}{*}{ E_\#02 } & E_F05 & CTCATTCGTTTCGGAAGAG & \multirow[t]{2}{*}{200} & & \multirow[t]{2}{*}{$\times$} & \multirow{2}{*}{$\begin{array}{c}10^{-6} \\
(1 \mathrm{fg} / \mu \mathrm{L})\end{array}$} \\
\hline & & & E_R75I & TAGAAGAATTCAGAIIITTAACACGA & & & & \\
\hline & \multirow{2}{*}{$\mathrm{N}$} & \multirow{2}{*}{ N_\#2 } & N_F10 & GCTGGACTTCCCTATGGT & \multirow{2}{*}{288} & & \multirow[t]{2}{*}{$\times$} & \multirow{2}{*}{$\begin{array}{c}10^{-6} \\
(1 \mathrm{fg} / \mu \mathrm{L})\end{array}$} \\
\hline & & & N_R20 & GCCATTGCCAGCCATTCTA & & & & \\
\hline \multirow{8}{*}{ Reference } & \multirow{2}{*}{ ORF1ab } & \multirow{2}{*}{ Ref.\#1 } & RdRp_SARSr-F & GTGARATGGTCATGTGTGGCGG & \multirow{2}{*}{100} & \multirow{6}{*}{$\begin{array}{l}\text { Corman } \\
\text { et al., } \\
2020\end{array}$} & \multirow{2}{*}{$\bigcirc$} & \multirow{2}{*}{$\begin{array}{c}10^{4} \\
(100 \mathrm{fg} / \mu \mathrm{L})\end{array}$} \\
\hline & & & RdRp_SARSr-R & CARATGTTAAASACACTATTAGCATA & & & & \\
\hline & \multirow[t]{2}{*}{ E } & \multirow[t]{2}{*}{ Ref.\#2 } & E_Sarbeco_F & & \multirow[t]{2}{*}{146} & & \multirow[t]{2}{*}{$\times$} & \multirow{2}{*}{$\begin{array}{c}10^{-6} \\
(1 \mathrm{fg} / \mu \mathrm{L})\end{array}$} \\
\hline & & & E_Sarbeco_R & ATATTGCAGCAGTACGCACACA & & & & \\
\hline & \multirow{2}{*}{$\mathrm{N}$} & \multirow{2}{*}{ Ref.\#3 } & N_Sarbeco_F & CACATTGGCACCCGCAATC & 112 & & ه & $10^{4}$ \\
\hline & & & N_Sarbeco_R & GAGGAACGAGAAGAGGCTTG & 1112 & & 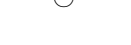 & $(100 \mathrm{fg} / \mu \mathrm{L})$ \\
\hline & E & Ref.\#4 & Forward & GGAAGAGACAGGTACGTTAA & 128 & Mollaei et al., & 0 & $10^{-5}$ \\
\hline & & & Reverse & AAGGTTTTACAAGACTCACG & & 2020 & & $(10 \mathrm{fg} / \mu \mathrm{L})$ \\
\hline
\end{tabular}

에 따른 검출 민감도가 $10^{-6}$ 수준 $(=1 \mathrm{fg} / \mu \mathrm{L})$ 으로 나타나 SARS-CoV2 진단에 적합한 프라이머 조합으로 확인되었 다(Fig. 2C). 한편, 기존 보고된 SARS-CoV2 RT-PCR 방 법 중 4개의 방법을 대상으로 비교한 결과, 3종류의 방법 (Ref. \#1, \#3 및 \#4)에서는 핵산에 반응 및 plasmid 기준 $10^{4} \sim 10^{-5}$ 수준 $(=10 \sim 1 \mathrm{fg} / \mu \mathrm{L})$ 의 검출 민감도가 확인되었으 나, ref. \#1은 SARS-CoV와 HuCoV-229E 핵산에 반응, ref. \#3은 SARS-CoV, MERS-CoV 및 RAdV 핵산에 반응 및 ref. \#4는 SARS-CoV, MERS-CoV 및 $\mathrm{HuCoV}-229 \mathrm{E}$ 에 각각 비특이적으로 반응함에 따라 SARS-CoV2만을 특이적으 로 검출할 수 없었다. 반면 $\mathrm{E}$ 유전자를 대상으로 하는 ref.\#2는 참고바이러스 핵산에서 비특이적 반응이 나타나 지 않았으며, plasmid 기준 검출 민감도 $10^{-5}$ 수준 $(=10 \mathrm{fg} /$ $\mu \mathrm{L}$ )으로 나타남에 따라 보고 및 검토한 방법 중에서는 가장 우수한 프라이머 조합으로 평가되었다. 그러나 본 연구에서 개발한 방법인 ORF1ab_\#06는 $10^{-7}$ (= $\left.100 \mathrm{ag} / \mu \mathrm{L}\right)$, E_\#02 및 $\mathrm{N} \# 02$ 는 $10^{-6}(=1 \mathrm{fg} / \mu \mathrm{L})$ 수준으로 나타남에 따 라 기존 방법 대비 검출 민감도가 약 10 100배 우수하였 다(Table 1).

\section{표준양성대조군 제작 및 평가}

이번 연구에서 개발한 RT-PCR 프라이머 3개 조합이 모두 반응하면서 위양성 반응을 검정할 수 있는 표준양 성대조군을 제작하였다. 염기서열은 총 812 nucleotide (nt) 길이로 $\mathrm{ORF} 1 \mathrm{ab}, \mathrm{E}$ 및 $\mathrm{N}$ gene의 프라이머 서열이 결합 및 반응할 수 있는 염기서열 부분이 포함되었다. 각 유 전자 별 프라이머 조합이 반응하여 형성하는 증폭 산물 [ORF1ab_\#06 $236 \mathrm{nt}$ (병원체에서 증폭 시 $232 \mathrm{nt}$ ), E_\#02 $202 \mathrm{nt}$ (병원체에서 증폭 시 $20 \mathrm{nt}$ ), N_\#2 $292 \mathrm{nt}$ (병원체에서 증폭 시 $288 \mathrm{nt}$ ) 형성]을 확인하였으며, sequencing 결과 2 4 nt의 염기서열이 각각 삽입되었다(Fig. 3A). PCR 증 폭산물들로부터 제한효소 EcoRV (GATATC) 반응 여부를 확인한 결과, ORF1ab_\#06 (146+90 nt), E_\#02 (132+70 nt) 및 N\#\#2 (190+102 nt)로 모두 두 개의 밴드가 나타났다 (Fig. 3B). 이에 따라 본 연구에서 개발한 SARS-CoV2 표 준양성대조군을 진단에 활용 시, 전기영동 상에서는 육안 으로 구분이 어렵지만, 증폭한 산물을 주형으로 제한효소 를 처리하면 밴드의 절단 유무에 따라 대조군으로 부터 오염으로 인한 위양성을 구분할 수 있다. 한편, $\mathrm{PCR}$ 기반 의 분자 진단에서 사용하는 양성대조군 예는 국내 질병 
(A)

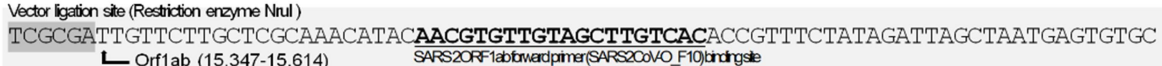

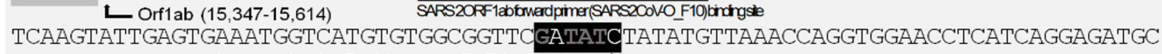

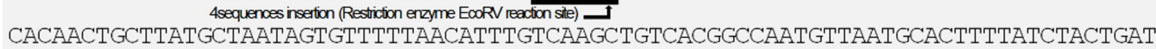
Orflab gene end 7 E $(26,246-26,471)$

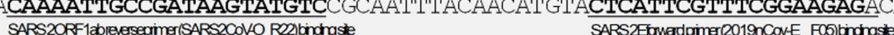
GTTAATAGCGTACTTCTTTTTCTTGCTTTCGTGGATATCTCTTGCTAGTTACACTAGCCATCCTTACTGCGCTTCGATT

2sequenoses insetion (Restidion enzyme Eoorv reacion site) -
GTGTGCGTACT GCT GCAATATTGTTAACGTGA GTCTTGTAAAACCTTCTTTTTACGTTTACTCTCGTGTTAAAAATCTG AATTCTTCTAGAGTTCCTGATCTTCTGGTCTACCAGAAGCTGGACTTCCCTATGGTGCTAACAAAGACGGCATCATATG

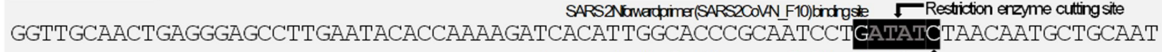

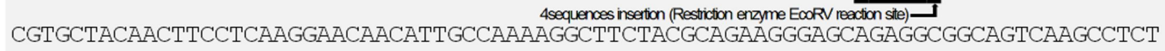
TCTCGTTCCTCATCACGTAGTCGCAACAGTTCAAGAAATTCAACTCCAGGCAGCAGTAGGGGAACTTCTCCTGCTAGAA

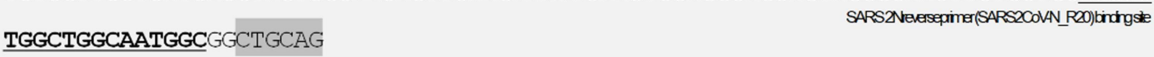

Vector ligation site (Restiction enzyme Pst)

B

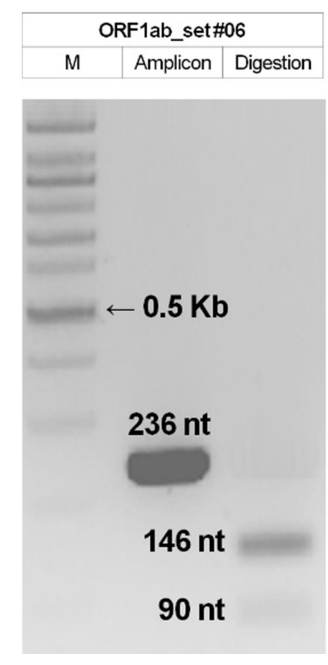

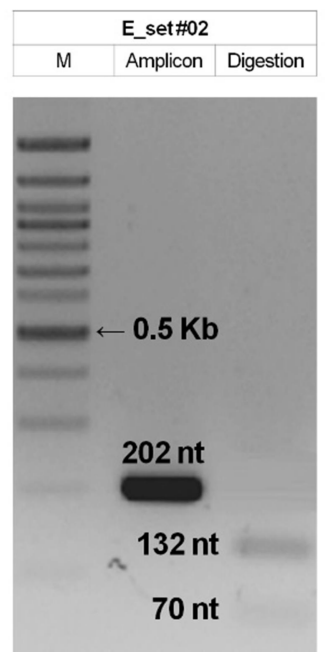

Insert

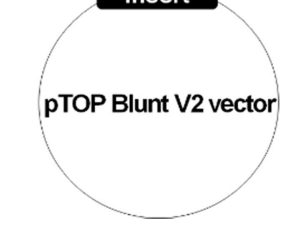

Fig. 3. Information and evaluation of standard positive control developed in this study. Panel A, Sequence information of standard positive control for the detection of SARS-CoV2. Panel B, Restriction enzyme EcoR V (GATATC) digested using the three RT-PCR products, respectively. Lane M, 100 bp DNA Ladder maker (Enzynomics); amplicon, RT-PCR product from standard positive control as a template; digestion, EcoR V digestion of RT-PCR product.
관리본부에서 제작한 노로바이러스 양성대조군, Virology Journal에 보고된 Lee et al. (2011) 등이 보고되고 있다. 해 당 보고들에서는 그러나 양성대조군으로부터 실험실 오 염이 일어날 경우가 있으므로 이를 검정할 수 있는 장치 가 고안되어야 하며, 해당 방법으로는 증폭 크기 변경 (Lee et al., 2011), 특정 염기서열 삽입(Lee et al., 2021) 등의 방법이 보고되고 있다. 이번 연구에서는 Lee et al. (2021)과 동일한 방법인 특정 염기서열 삽입을 선택하였고, 하나의
표준양성대조군으로부터 SARS-CoV2 3개 유전자 검출이 모두 가능할 수 있도록 성능을 향상하였다. 또한 본 연구 에서 개발한 프라이머 조합 외에도 Corman et al. (2020), Mollaei et al. (2020) 등 프라이머 결합 위치가 일치하는 몇 몇의 방법과 함께 활용될 수도 있다. 이번 연구에서 개발 한 표준양성대조군은 유전자 클로닝을 통해 안정적으로 보관이 가능하고, 특정 농도로 제공 및 공급이 될 수 있 어 본 연구에서 개발한 프라이머 조합들과 함께 SARS- 
$\mathrm{CoV} 2$ 진단에 유용하게 활용될 수 있을 것으로 기대된다.

\section{개발 프라이머 및 표준양성대조군을 이용한 시험 과정 및 고찰}

SARS-CoV2의 특정 핵산을 증폭하는 검사 플랫폼을 사용하는 경우는 세계보건기구 및 유럽연합 등의 기관과 Corman et al. (2020), Mollaei et al. (2020) 등 다수의 연구 보고에서 ORF1ab (RdRp), E 및 N 유전자를 대상으로 하 고 있다. 동일한 시료에서 추출된 총 핵산으로부터 다양 한 종류의 병원체 또는 유전자를 진단할 경우, 검사 대상 항목이 많아 질수록 PCR 조성 및 조건이 상이할 경우 검 사자와 현장에서의 활용성에 제한될 수 있다(Lee, 2013; Lee et al., 2015). 그러나 기존의 연구 보고에서는 다수의 검사자에 의해 개발된 방법들로 보고된 방법마다 PCR 조성물과 조건이 상이했으며, 동일한 보고 내에서도 프 라이머 및 어닐링 $\mathrm{Tm}$ 값이 달라서 조건이 다른 경우도 존재하였다. 그러나 본 연구에서는 개발한 3 개의 방법에 대한 조성물 및 조건이 모두 동일하게 개발되면서 이러 한 문제점들을 극복하고자 하였다. RT-PCR 조성물은 AccuPower $^{\circledR}$ RT/PCR PreMix (Bioneer, Daejeon, Korea) dry type, 정방향 및 역방향 프라이머 각각 $25 \mathrm{pmol}$ 농도로 $1 \mu \mathrm{L}$ 씩(총 $2 \mu \mathrm{L}$ ), 주형 핵산 $1 \mu \mathrm{L}$ 및 nucleic acid free water $17 \mu \mathrm{L}$ 로 총 $20 \mu \mathrm{L}$ 가 사용되며, 3 개 유전자는 각각 다른 프라이머가 사용되며 그 밖의 조성물들의 농도와 부피는 동일하다. RT-PCR 조건은 역전사 $\left(42^{\circ} \mathrm{C}, 60\right.$ 분), 초기 변성 ( $95^{\circ} \mathrm{C}, 5$ 분), 35 회 반복[변성 $\left(95^{\circ} \mathrm{C}, 45\right.$ 초 $)$, 결합 $\left(55^{\circ} \mathrm{C}, 60\right.$ 초) 및 신장 $\left(72^{\circ} \mathrm{C}, 60\right.$ 초 $\left.)\right]$, 최종 신장 $\left(72^{\circ} \mathrm{C}, 5\right.$ 분)으로 동일하여 각자 다른 튜브를 사용해야 하지만 한 대의 thermocycler에 서 동시 반응이 가능하게 하여 검사자 친화적(user friendly) 및 현장 활용성을 고려하였다. 한편, 위양성을 검정할 수 있는 표준양성대조군의 개발로 SARS-CoV2 진단에 높은 정확성을 지원할 수 있을 것으로 보인다. 개발한 표준양 성대조군으로부터 증폭이 일어나면 제한효소 $\mathrm{EcoRV}$ 반 응으로 밴드패턴에 의해 위양성 판정이 가능하다. 그러 나 또한 개발한 표준양성대조군은 DNA 형태이므로 시 료에서 total RNA를 추출하여 시험을 진행하여 추정 양성 밴드가 확인되었다면, AccuPower ${ }^{\circledR}$ HotStart PCR PreMix (Bioneer) 등 역전사 효소가 포함되지 않은 PCR kit를 사 용하는 재 시험을 통해 오염 여부를 확인할 수도 있다. 시료에서 total RNA 추출 후 RT-PCR 시험 설계 시 개발한 표준양성 대조군을 양성, nucleic acid free water를 음성대 조군으로 설정하여 3 개 유전자 대상으로 모두 일반 RT-
PCR 검사를 수행하여 $2 \%$ agarose gel에서 전기영동 및 각 각의 추정 양성을 판정 한 후, 추정 양성 밴드가 존재할 경우 위양성 판정을 수행한다. 위양성이 아닌 것으로 분 석되면 추정 양성 밴드에 대해 sequencing하여 염기서열 을 기초로 NCBI BLAST 등으로 최종 동정 및 계통수 구 축 등과 같은 유전형을 분석할 수 있다. 그러나 향후 다 수의 시료에 대한 점검이 필요할 것으로 보이며, 현장 모 니터링 검사 등의 기간을 거쳐 향후 호흡기 바이러스 유 관 분야의 진단 및 연구에 활용성이 기대된다.

\section{ACKNOWLEDGEMENT}

This work was supported by the Shihan University Research Fund, 2021

\section{CONFLICT OF INTEREST}

The authors have declared no conflict of interest.

\section{REFERENCES}

Andersen KG, Rambaut A, Lipkin WI, Holmes EC, Garry RF. The proximal origin of SARS-CoV-2. Nature Med. 2020. 26: 450-452.

Carroll A, McNamara E. Comparison and correlation of commercial SARS-CoV-2 real-time-PCR assays. Euro Surveill. 2021. 26: 2002079.

Cho KB. Development of nested PCR primer set for the specific and highly sensitive detection of human Parvovirus B19. Biomed Sci Lett. 2018. 24: 390-397.

Corman VM, Landt O, Kaiser M, et al. Detection of 2019 novel coronavirus (2019-nCoV) by real-time RT-PCR. Euro Surveill. 2020. 25: 2000045.

Domenico MD, Rosa AD, Boccellino M. Detection of SARSCOV-2 proteins using an ELISA test. Diagnostics (Basel) 2021. 11: 698 .

Hall T. BioEdit: A user-friendly biological sequence alignment editor and analysis program for windows 95/98/NT. Nucleic Acids Symp Ser. 1999. 41: 95-98.

Jung S, Lee DY, Choi W, Kang C. Introduction of reference materials for water- and food-borne disease viruses. Public Health Weekly Rep. 2018. 9: 254-259.

Gorbalenya AE, Baker SC, Baric RS, et al. The species Severe acute respiratory syndrome-related coronavirus: classifying 2019-nCoV and naming it SARS-CoV-2. Nature Microbiol. 
2020. 5: 536-544.

Lee S. A study of molecular biological detection methods for seedtransmitted viruses in quarantine. Ph. D. thesis. 2013. Dankook University, Cheonan, Chungcheongnam-do, Korea.

Lee S, Cho KB. Development of reverse transcription semi-nested PCR primer pairs for the specific and highly sensitive detection of human Aichivirus A1. Biomed Sci Lett. 2019. 25: 331-338.

Lee S, Bae KS, Lee JY, et al. Development of molecular diagnostic system with high sensitivity for the detection of human Sapovirus from water environments. Biomed Sci Lett. 2021. 27: 35-43.

Lee S, Lee JY, Moon BY, et al. Development of a diagnostic system for the detection of the Cowpea mild mottle virus specific gene in quarantine. Microbiol Biotechnol Lett. 2015. 43: 296-299.

Lee SG, Lee SH, Park SW, et al. Standardized positive controls for detection of norovirus by reverse transcription PCR. Virol J. 2011. 260: 1-8.

Mollaei HR, Afshar AA, Kalantar-Neyestanaki D, Fazlalipour M, Aflatoonian B. Comparison five primer sets from different genome region of COVID-19 for detection of virus infection by conventional RT-PCR. Iran J Microbiol. 2020. 12: 185193.

Reuter G, Boldizsar A, Papp G, Pankovics P. Detection of Aichivirus shedding in a child with enteric and extraintestinal symptoms in Hungary. Arch Virol. 2009. 154: 1529-1532.

Santos N, Mendes GS, Silva RC, Pena GA, Rojas M, Amorim AR, Lima DP. Salivirus and aichivirus A infections in children with gastroenteritis in Brazil. Clin Microbiol Infect. 2015. 21: 799.e1-799.e3.

van Doremalen N, Bushmaker T, Morris DH, et al. Aerosol and surface stability of SARS-CoV-2 as compared with SARSCoV-1. New England J Med. 2020. 382: 1564-1567.

Yamashita T, Ito M, Kabashima Y, Tsuzuki H, Fujiura A, Sakae K. Isolation and characterization of a new species of kobuvirus associated with cattle. J Gen Virol. 2003. 84: 3069-3077.

Zhou P, Yang XL, Wang XG, et al. A pneumonia outbreak associated with a new coronavirus of probable bat origin. Nature. 2020 . 579: 270-273.

https://doi.org/10.15616/BSL.2021.27.4.283

Cite this article as: Cho KB. Development of Reverse Transcriptase Polymerase Chain Reaction Primer Sets and Standard Positive Control Capable of Verifying False Positive for the Detection of Severe acute respiratory syndrome coronavirus 2. Biomedical Science Letters. 2021. 27: 283-290. 